Meta

Journal des traducteurs

Translators' Journal

\title{
How Balkan Am I? Translation and Cultural Intimacy Through an Albanian-Greek Lens
}

\section{Dimitris Asimakoulas}

Volume 61, numéro 2, août 2016

URI : https://id.erudit.org/iderudit/1037767ar

DOI : https://doi.org/10.7202/1037767ar

Aller au sommaire du numéro

\section{Éditeur(s)}

Les Presses de l’Université de Montréal

ISSN

0026-0452 (imprimé)

1492-1421 (numérique)

Découvrir la revue

Citer cet article

Asimakoulas, D. (2016). How Balkan Am I? Translation and Cultural Intimacy Through an Albanian-Greek Lens. Meta, 61(2), 439-458.

https://doi.org/10.7202/1037767ar

\section{Résumé de l'article}

Les historiographes, les anthropologues et les experts en études culturelles ont montré que les discussions concernant l'identité dans les Balkans ou à propos des Balkans ont été traditionnellement associées à un sens d'« insuffisance ". Étant donné l'histoire de conflits, l'effort concerté vers une plus grande intégration européenne et les retombées de la crise économique dans la région, il devient urgent de déconstruire de telles idéologies. Cet article montre comment l'approche de Herzfeld $(2002 ; 2005)$ concernant la marginalité balkanique peut être étendue afin d'inclure la critique culturelle et la critique de traduction. J'applique son concept de l'intimité culturelle aux histoires des migrations. J'examine deux oeuvres grecques : A Short Border Diary (2006), roman à demi autobiographique de Gazmend Kapllani et traduit en anglais par Marie Stanton-Ife, et Plato's Academy, un film réalisé par Filippos Tsitos (2009), sous-titré en anglais. Les deux oeuvres ont créé un précédent en ce qui concerne la réception par le public et en tant que documents d'un cycle historique, c'est-à-dire la migration de milliers d'Albanais vers la Grèce après la chute du communisme. La traduction et le sous-titrage en anglais montrent respectivement que le médium écrit et le médium audiovisuel offrent différentes possibilités de communiquer l'altérité balkanique.
Tous droits réservés @ Les Presses de l’Université de Montréal, 2016
Ce document est protégé par la loi sur le droit d'auteur. L’utilisation des services d'Érudit (y compris la reproduction) est assujettie à sa politique d'utilisation que vous pouvez consulter en ligne.

https://apropos.erudit.org/fr/usagers/politique-dutilisation/ 


\title{
How Balkan Am I? Translation and Cultural Intimacy Through an Albanian-Greek Lens
}

\author{
DIMITRIS ASIMAKOULAS \\ University of Surrey, Guildford, United Kingdom \\ D.Asimakoulas@surrey.ac.uk
}

\begin{abstract}
RÉSUMÉ
Les historiographes, les anthropologues et les experts en études culturelles ont montré que les discussions concernant l'identité dans les Balkans ou à propos des Balkans ont été traditionnellement associées à un sens d'«insuffisance». Étant donné l'histoire de conflits, l'effort concerté vers une plus grande intégration européenne et les retombées de la crise économique dans la région, il devient urgent de déconstruire de telles idéologies. Cet article montre comment l'approche de Herzfeld $(2002 ; 2005)$ concernant la marginalité balkanique peut être étendue afin d'inclure la critique culturelle et la critique de traduction. J'applique son concept de l'intimité culturelle aux histoires des migrations. J'examine deux œuvres grecques: A Short Border Diary (2006), roman à demi autobiographique de Gazmend Kapllani et traduit en anglais par Marie Stanton-Ife, et Plato's Academy, un film réalisé par Filippos Tsitos (2009), sous-titré en anglais. Les deux œuvres ont créé un précédent en ce qui concerne la réception par le public et en tant que documents d'un cycle historique, c'est-à-dire la migration de milliers d'Albanais vers la Grèce après la chute du communisme. La traduction et le sous-titrage en anglais montrent respectivement que le médium écrit et le médium audiovisuel offrent différentes possibilités de communiquer l'altérité balkanique.
\end{abstract}

\begin{abstract}
Historiographers, anthropologists and cultural studies experts have shown that discussions of identity in or about the Balkans have been traditionally linked to a sense of 'deficiency.' Given the history of conflict, the drive towards greater European integration and the effects of the current economic crisis in the region, there is an urgency to deconstruct such ideologies. This article shows how Herzfeld's (2002; 2005) approach to Balkan marginality may be productively extended to cover cultural and translation critique. Thus his concept of cultural intimacy is applied to stories of migration. Two Greek works are examined: Gazmend Kapllani's semi-autobiographic novel A Short Border Diary (2006), translated into English by Marie Stanton-Ife, and Filippos Tsitos' film Plato's Academy (2009), subtitled into English. Both works have set a precedent in terms of audience reception and as documents of a historical cycle, the migration of thousands of Albanians to Greece after the collapse of communism. Translation and subtitling into English respectively show that the written and the audiovisual medium present different opportunities for conveying Balkan otherness.
\end{abstract}

\section{MOTS-CLÉS/KEYWORDS}

albanais, grec, humour, minorité, traduction audiovisuelle Albanian, Greek, humour, minority, audiovisual translation

\section{Crossroads}

On 22 February 2010, after the Greek government failed to accurately register the exact size of the national deficit, and with various European institutions agonising 
over a possible bailout package, the German magazine Focus published a controversial issue. Among the lead articles detailing the domino effect of national debt in Europe there was also a broad-brush history overture. An article entitled 2000 Jahre Niedergang ('2000 Years of Decline') covered mainly classical antiquity and the pre/ post-Ottoman period, explaining how Greece has nothing to offer to modern civilization (Klonovsky 2010). The cover featured Venus de Milo, complete with a hand nonchalantly showing a middle finger and wearing a Greek flag in tatters (the issue was entitled: Betrüger in der Euro-Familie, 'Deceivers/cheats in the Euro-family'). A mini cultural war between German and Greek media ensued. Greek responses consisted of mentions of yet unresolved World War II reparations and frequent use of Nazi imagery, an exaggerated dismissal of Germany's hegemonic role in Europe. The German media countered with further crass portrayals of 'southern incompetence.'

This incident shows the partial nature of translation vis-à-vis identity projection. Translation allowed stereotypes to travel in the first place; attempts to deconstruct these clichés later also involved translation (support for research on Greco-German relations, promotion of Greek literary works in German translation; Pappas 2014). More importantly, the incident points to general principles of rehearsing identity narratives in/about the Balkans. In Europe's periphery, identity seems to revolve around a perceived lack or deficiency. Balkan nations are and are not part of Europe because of their Ottoman/post-socialist heritage or their economic backwardness. Historiographers and cultural theorists have traditionally examined such perceptions of identity by tracing commonalities and differences in each Balkan nation's course towards modernity (Tziovas 2003; Todorova 2009; Longinović 2011; Calotychos 2013). Unsurprisingly, references to translation are rare and modern texts are seldom examined. At the same time, Translation Studies has ventured beyond Euro-centric views on translation practice and theory in order to make sense of a post-modern, postcolonial world. In spite of, or perhaps because of this shift, the Balkans have been neglected (Kuhiwczak 1999; Jones 2004; Stahuljak 2010). In her critique of postcolonial translation studies, Stahuljak argues that a lot remains to be learnt about power relations and identity by looking at Europe's margins, an area that has experienced shifting centres/peripheries, heterogeneity and (in)tolerance of neighbours (Stahuljak 2010: 261, 267-268).

This paper will address the question of how Balkan marginality may be negotiated in cultural products. In order to explore the issue of deficient identities, I will borrow an ethnography concept, cultural intimacy, which I will apply to a written and a multimodal product. Both works have been translated from a minor language, Greek, into English and feature characters who represent a European peripherywithin-a-periphery, that is, migrant 'strangers.' This topic has not been systematically researched in Greek Studies (see Calotychos 2013; Gotsi 2012) and the examples selected here set a historical precedent, not least, in terms of identification/reception.

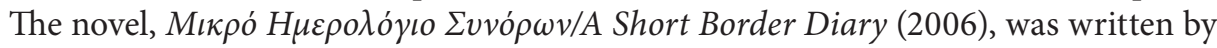
Gazmend Kapllani, an Albanian immigrant (the very first, at that) who acquired

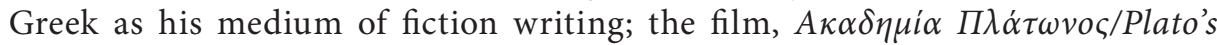
Academy (2009), was directed by Filippos Tsitos, a native Greek who has lived in Germany since the mid-1990s. Both were successful in Greece and moderately successful abroad. The more specific questions I will be exploring concern, first, the way in which motivated aesthetic choices allow the management of division lines between 
'us' and 'them' and, second, the implications of this for the translator's/subtitler's voice. Sections 3 and 4 will address these questions, but first some theoretical bridges are necessary.

\section{Deficient identities: 'if you're not like us...'}

The term 'Balkan' signals a sort of transitory, ambiguous state of Europeanness. As such it is revealing about how identity narratives are rehearsed vertically (by Western Europe) and horizontally (in the Balkans). The image of the Balkans in Western historiography, academic discourse and the media has been linked to an internationalised stereotype. The historian Maria Todorova calls this balkanism: barbarity, tribalism, backwardness, inefficiency and unpredictability, all contrasting with the idealised classical/Judeo-Christian values and commitment to modernity of Western European perfection (Todorova 2009: 29-36, 119, 184). From the $18^{\text {th }}$ century until now, Western European powers/nations tried to protect vested interests and to manage relations with the (Ottoman) East and (Soviet) Russia. In this process, they foregrounded their technologically advanced civilization, forgot their 'story of becoming,' a story of (world) wars and bloodshed, and projected their own historical traumas onto the Balkans (Longinović 2011: 27, 45). This explains, for instance, why public narratives presented the Wars of the Yugoslav Succession as inexplicable/unEuropean cycles of revenge.

The horizontal model concerns how identity is understood internally. Todorova calls this the "bearable heaviness of being Balkan" and attributes it to nestling orientalisms, that is, the processes of Balkan peoples measuring themselves and each other against an idealised European yardstick (Todorova 2009: 45, 58). Balkan peoples manage the stigma of marginality by presenting themselves as defenders of European modernity. Thus they may suppress their common cultural stock and "separate their identity from the 'Balkan-ness' of their neighbours" (Calotychos 2013: 17). Herzfeld uses the more nuanced term crypto-colonialism. By this he refers to independent contact zones between colonial and untamed lands that gained nominal political independence at the expense of massive economic dependence, something that compelled such states to aggressively model their cultures after those of their benefactors (Herzfeld 2002: 900-901; Herzfeld 2005: 67). Since the $19^{\text {th }}$ century, when Greece gained its independence with the help of powerful allies, it has been trying to de-Ottomanize and de-Balkanize itself (Tziovas 2003). In the $20^{\text {th }}$ century it projected a Western face through close adherence to ideals of progress and, eventually, full participation in European political structures, setting an example for other Balkan nations.

Herzfeld argues that such historical conditions have led to a sort of cultural diglossia, a tension between the image Greeks present to the outside world and what they privately know to be the case. He calls this cultural intimacy: "The recognition of those aspects of cultural identity that are considered a source of external embarrassment but that nevertheless provide insiders with their assurance of common sociality" (Herzfeld 2005: 3). Herzfeld coined the term while conducting ethnographic work in Greece. He felt that Greeks experience a particularly acute tension between self-knowledge and self-display. They project a public image of classicism (the pillar of European identity) to outsiders but critically attribute national failings to their Eastern origins (Herzfeld 2005: 89, 130-31). Cultural intimacy explains how 
contradictory ideas and practices are shared between institutions or between individuals and institutions, often in the knowledge that outward presentation is unrealistic. The collusion between corrupt officials and individuals who read laws in a subversive way is an example of this (Herzfeld 2005: 55). Thus, cultural intimacy can be strategic; it may serve official norms when outward signs of identity are presented as fixed/timeless or it may mock, reject and appropriate these norms. For example, although simplistic official discourses on national identity, patriotism and morality are widely accepted, a large number of Greeks acknowledge that they have 'foreign' ancestry (Albanian, Slavic), love the overtly Turkish characteristics of their language, food, and music, engage in sexual activity that contravenes local morality and indulge in tax evasion whilst citing a national stereotype of defiant independence (Herzfeld 2005: 216).

Contexts of immigration offer apt examples of how public presentation of fixity and real-life complexity clash. When socialist states collapsed in the 1990s, Greece became a destination for migrants, including (ironically) ethnic-Greeks from Southern Albania or former Soviet republics, Albanians, and, from the late 2000s onwards, immigrants from conflict zones in the Middle East, Asia and Africa. Legally, economically and institutionally ill-equipped to cope with the new realities of mass migration, Greece revised sclerotic official models of identity based on bloodline and tradition and became a defender of "Fortress Europe policies" (Christopoulos 2009: 122). Currently, Greece has some of the strictest asylum and naturalisation laws in the European Union (EU), it patrols its extended, porous borders and ostensibly safeguards EU security and freedoms; in real practice, it quashes personal freedoms and constitutes a byword for the casualization of immigrant labour in the EU (see Calotychos 2013: 163; Tsianos and Karakayali 2010: 385). Geographic proximity to central Europe has rendered Greece an ideal entry point for illegal immigrants. This, in combination with recent EU legislation dictating that asylum applications be processed at the first entry point has meant that immigrants throughout Europe are sent back to Greece, turning it into a "storehouse" of illegal immigration to Europe" (Kasimis 2012). Such failings clash with the administrative pretensions of the Greek state and with official claims that Greeks cannot be racist on account of a culturally ingrained 'philoxenia,' that is, hospitality (Cheliotis 2013).

Books, films and other means of artistic expression describing migrant experiences can expose relevant cultural intimacies. The double standards of public discourse on economic development, security, legal rights and social cohesion in Greece (or any other host culture) are a source of embarrassment. Similarly, the embarrassment that migrants themselves feel as linguistic and cultural pariahs can cause critical self-reflection, especially when migrants voice their stories, allowing the host culture to see itself through the eyes of a stranger. Previous work on the Spanish/ Catalan, Australian and German contexts (Carbonell 2003; Svensson 2010; Wright 2010, respectively) has shown that ambiguity in cultural references (for example, food, customs, proper names) and linguistic heterogeneity (code-switching) can be seen as relevant (de)familiarisation techniques. In what follows I would like to show how a strategic use of Balkan strangerhood can be achieved through cultural ambiguity, the use of foreign languages (Albanian) and ironic characterisation. By looking at stories of migrants in the Balkans, I also attempt to make the concept of cultural intimacy more general and more specific at the same time; thus I adapt it vis-à-vis 
the following three dimensions: a) the general sense of getting to know a culture other than one's own; b) the realisation that in many ways this 'Balkan other' is not so different from the 'self'; c) the move away from one's comfort zone in relation to a) and b); this move can be refracted through translation and subtitling in specific ways, given that similarity and otherness can be inscribed in language or audio/visual signs. This is cultural intimacy in its more concrete manifestation of semiotic transfer.

As will be shown below, A Short Border Diary (2006) and Plato's Academy (2009) are prototypical products relying on Balkan cultural intimacy. Both of them were produced at the end of an Albanian migration cycle that King calls "the most dramatic example of post-Iron Curtain mass migration” (King 1998: 299-301). By 2009, hundreds of thousands of Albanians established themselves in Greece. Thus, looking through their eyes may bring the bearable heaviness of being Balkan into sharp relief.

\section{A handbook without borders}

Gazmend Kapplani was born in 1967 in Lushnjë, Albania, and immigrated to Greece in 1991. He took up various 'immigrant jobs' (builder, cook, kiosk attendant) and enrolled as a student, obtaining a BA from the Department of Philosophy, Pedagogy and Psychology of the University of Athens. After securing a PhD scholarship, he received a doctorate in political science and history from the Panteion University of Athens in 2007. He freelanced as a columnist in Greek newspapers, lectured at Panteion University and recently became a Rita E. Hauser fellow at Harvard

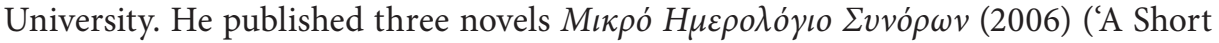

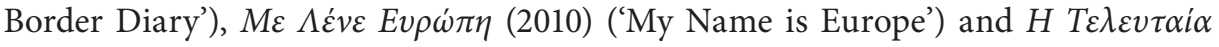
$\sum \varepsilon \lambda i \delta \alpha$ (2012) ('The Last Page'). His best-selling, semi-autobiographic 'A Short Border Diary' is the first piece of Greek migrant literature (literature written by a migrant). It tackles a contemporary topic and as such it marks a moment of moving away from historical migration literature (literature about migration) that typically examines the imposition of borders after $20^{\text {th }}$ century wars (Farinou-Malamatari 2003: 257-258).

His book consists of a collage of migrant experiences with the main focus being the narrator's trajectory of migration. The story begins before the Albanian borders open in the early 1990s and life under Enver Hoxha's regime. Then it shows how five characters converge at the immigrant reception centre of Filiates: the narrator (Kapllani) from Lushnjë, two drivers from Tirana, Xhemal from Elbasan and Marenglen from an unidentified Albanian village. They all try to find work in the neighbouring town of Igoumenitsa, but as relations with the police who supervise them go sour and living conditions at the reception centre deteriorate, they plan their escape. Out of the five characters only two manage to escape: Xhemal (with the help of some shady connections) and the narrator (with the help of activists attracted to the plight of immigrants at Filiates). The book's epilogue shows the narrator/main protagonist living in Athens but still beset by the limitations of strangerhood.

Each chapter is divided into two sections; the first features a chapter number and is written in italics. The second starts with a header and is written in normal fonts (the prologue and epilogue are stand-alone italicised chapters in the ST). In the first section the diarist-narrator uses the first person and the past tense of memory. In the second section, there is second- and third-person narration typically featuring the simple present tense and evoking the universal migrant condition in a reflective style 
that recalls Kapllani's journalism. For ease of reference, I shall refer to these sections as 'personal' and 'communal' respectively. Both sections complement each other in conveying the cultural intimacies of the migrant underdog: European humanism/ modernity advocates appealing, capitalist lifestyles and equality, but in actual practice migrants do not experience these, even though they are just like their hosts. Sameness and denial of agency/power become critical commentary as they are 'overperformed,' to use Herzfeld's term (2005: 55).

The English translation, A Short Border Handbook (2009), was done by AnneMarie Stanton-Ife, a literary translator translating from Greek and Norwegian into English. ${ }^{1}$ Her choices in the Target text (TT) contribute to the management of cultural intimacy. I will focus on four such techniques: the use of foreign words, the labelling of migrants/migration, the ironic presentation of host culture norms and rewriting.

Foreign languages, such as English, French and Italian are reported to be used in the novel by the narrator or other characters who try to translate for their fellowAlbanians and/or communicate with locals, policemen and journalists (Chapters 9, $12,22,23,29,30)$. As Kapllani wryly notes, the aggressive propaganda and censorship of the Enver Hoxha regime resulted in a boom of foreign language learning. This way Albanians could illegally listen to radio stations and watch TV channels from the West (Chapters 2, 7). There is also some limited use of Albanian in the novel. When communicating with the authorities and with a Greek priest who visits the reception centre (Chapters 10, 22, 23, 27) characters use kinship terms, such as babai ('father') and papou ('grandfather'); the former is explained in the first instance in the Source text/Target text and then left untranslated; the latter can be understood from the context in the ST/TT. In Chapter 17 the adjective fukara ('wretch/unfortunate' or 'poor person'), used when communicating with a local bus driver, is left untranslated in both the ST and the TT and can be understood from the context; yet the figurative 'wretch' can be understood only by Greek readers. Finally, a comforting folk song Ore bilbil ('oh nightingale') is sung by immigrants at the reception centre (Chapter 25). The Albanian song is translated in a footnote in the ST and in an endnote in the TT. In this case it is only Greek readers who can readily recognize the genre of folk songs, harking back to the oral of (pre)Ottoman Balkan tradition (see Nitsiakos and Mantzos 2003 for a discussion of polyphonic folk songs in Northern Greece/Southern Albania). Greek readers can also appreciate cognates in all of the above examples. In the folk song, for instance, Greek shares the interjection ore and other words, such as pabesë ('double-crosser') with Albanian. By using such expressions throughout, the novel highlights a common cultural stock between Greeks and Albanians.

Perhaps in order to compensate for such losses, the translation occasionally introduces foreign words in the TT by keeping some of the Greek untranslated and glossing it in English (Chapters 9, 18, 22, 24). A characteristic case is an excerpt from the communal section of chapter 16 , where a migrant's attempt to learn Greek is described:

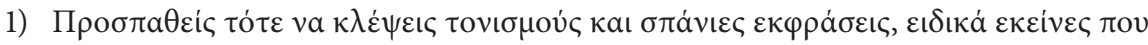

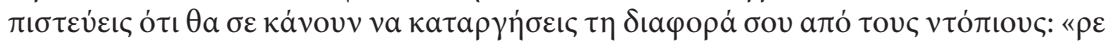

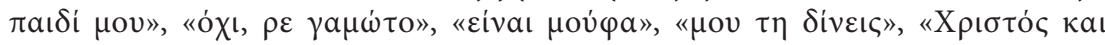

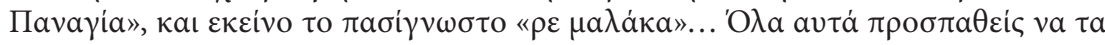

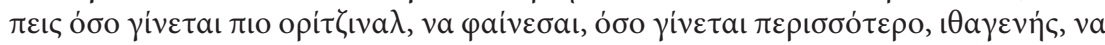

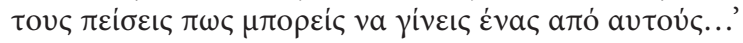


[Then you try to steal stresses and rare expressions, especially those you think will make you suppress your difference from the locals: ' $r e$ [particle] my child,' 'no, re[particle] fuck-it,' 'it is a lie/shoddy' [+slang], 'you-give-her-to-me[idiom:do my head in],' 'Jesus and Holy-Mary,' and that renowned 're[particle] maláka[:wanker]...' All this you try to say as original[:EN loan], to seem, as far as possible, a native, to convince them that you can become one of them...]

(Kapllani 2006: 96)

You try to import unusual phrases and expressions into your speech, especially the ones you think will bridge the gulf between you and the native speakers: oxi re gamoto (oh! Fuck!); einai moufa (crap, rubbish); mou ti dineis (you really piss me off); Christos kai Panagia (Jesus and Mother of God!) as well as the ubiquitous re malaka (wanker, arsehole). All this you try to say in as convincing an accent as you can, hoping to pass for a native and convince them that you can become one of them.

(Kapllani 2009: 79, translated by Stanton-Ife)

The ST features a series of language fragments: idioms ('re my child,' 'you give it to me,' 'Jesus and Holy-Mary'), taboo language ('re fuck-it,' 're maláka'), and sociolectal variants ('it's a lie/shoddy,' 'original'). Some of these feature the untranslatable particle re, which may signal emphasis, (friendly) disagreement, a commonly known narrated entity, or in-group membership (combined with a kinship term 'my child' and an informal in-group swear word 'maláka,' for instance). The mixture of expressions reflects unevenly developed vocabulary based on random encounters with natives of various ages. The expression for 'it's a lie' signals youth slang and 'Jesus and Holy-Mary' older generations, for example. The translator omitted a loan word from English ('original') and a kinship term of address ('my child'), both of which would make no sense in English. She then provided a mixture of graphologi$\mathrm{cal} /$ phonological translations with idiomatic glosses in brackets that effectively mirror usage in high familiarity contexts. The glossing here allows English-speaking readers to ventriloquize the migrant's attempt at mastering Greek. They get a glimpse into the everyday experiences of Albanian migrants through an enforced act of linguistic performance, one the translator prepared for them.

Labels for the state of migrancy or for migrants have a similar effect, because once again they may expose what is commonly known but 'officially denied.' This is the case with the word $\xi \boldsymbol{\varepsilon} \boldsymbol{v} \iota \boldsymbol{\tau} \mathbf{a}$ (/ksenitiá/) used in the communal sections of Chapters 2, 6, 18, 22-27. Ksenitia can be rendered into English as a generic reference to a place, that is, 'foreign land(s)'; more crucially, it denotes the state of living abroad but still experiencing an intense feeling of rootlessness. Ksenitia is commonly used in songs, poems and novels that deal with the theme of Greek migration, so much so, that it becomes self-explanatory that it 'should' mean an outward movement from Greece to other places. The fact that it is used to discuss migration flows towards Greece shows that foreigners living there are in a state of ksenitia too. The translator occasionally tries to address this intimation of sameness by highlighting the emotive load of the term. Renderings such as "exile" or "far away from home" are relevant examples. In all other cases, she merely resorts to circumlocutions, such as "migrant existence," "foreign land," "the life of/as a migrant," "being a migrant," "being in another country."

A similar technique of projecting the self into the other and the other into the self can be seen when labelling migrants. Kapllani occasionally employs Greek words 
with archaic roots that serve as allusions to Greece's emigrating history; one such example is $\mu$ غ́ токкос, 'metic,' or person who changed their 'polis' in ancient Greece. It is not clear whether all Greek readers are aware that a metic had partial rights of citizenship in their new place of residence; however, given the diglossic past of the Greek language, the term can be readily recognised as formal and ancient. The repeated use of metic by/for someone who is not Greek in Chapters 10, 22, 28 and 29 creates an ambiguity between past and present. The term is translated as "migrant," thus resulting in functional loss here.

Apart from the use of labelling and of mixing codes in the novel, there is a very frequent use of what can be described as comedy torture. Elsewhere I have called this bitter wit (Asimakoulas 2013: 5), or the repetitive satirical characterization of migrants as 'losers': migrants are drawn to modernity, the "empire of consumption" (chapter 8), but they can never be part of it. The reasons become obvious. Exploitative majorities police in-group/out-group boundaries because they benefit from relations of dependence. The stigma of cultural difference is a euphemism for this. The translator mediates this perspective by highlighting ironies. In chapter 12 , for example, the story of an Albanian visiting the supermarket for the first time borders on the absurd:

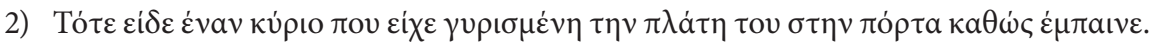

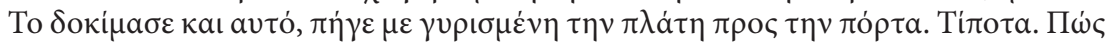

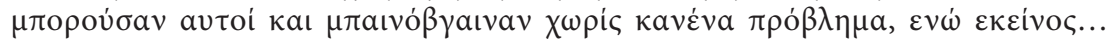

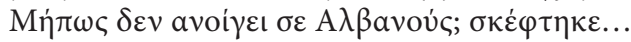

[Then he saw a man who had his back turned to the door as he entered. He tried that too, he went with his back turned towards the door. Nothing. How could they all go-in-and-out without any problem, while he... Mipos[:doubt particle] it does not open to Albanians? he thought...]

(Kapllani 2006: 78-79)

Then he spotted a gentleman reversing through the doors. Interesting. He tried that too, turning his back to the door. Nothing. He was at a loss. How come all these people were entering and leaving the supermarket so effortlessly, while he, no matter what he tried, failed? Perhaps the door had a thing about Albanians. That might be it.

(Kapllani 2009: 64, translated by Stanton-Ife)

The TT features some expansions that show more clearly the thoughts ('interesting,' 'that might be it') and speech patterns of the caricatured Albanian migrant. Free indirect discourse is marked by bringing the question mark forward to the third sentence from the end, where the ST uses suspension dots, and by raising the level of orality ('how come,' 'had a thing'). By mimicking/explaining internal speech, the narrator in the translated version holds two perspectives in suspension: he laughs at and with the failing migrant, thus creating more overt points of contact with the readers than in the ST. Readers in English are overtly invited to feel empathetic and superior at the same time. Amplifications of this kind occur in most instances where free indirect discourse is used throughout the novel.

In tandem with such interventions there is a tendency to use ironic expansions. For instance, chapter 22, entitled 'Tough Profession' to refer to migrant existence, details the difficult relation between marginality and basic human rights: 


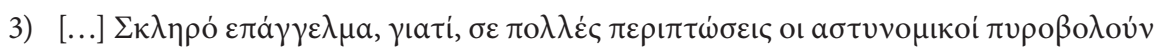

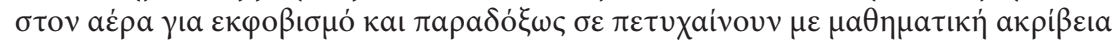

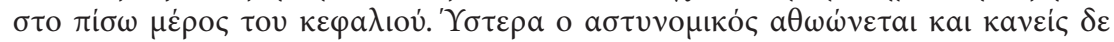

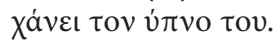

[[...] Tough profession because, in many cases policemen shoot in the air for intimidation and paradoxically they target you with mathematical precision at the rear side of the head. Then the policeman is exonerated_and no one loses his sleep.]

(Kapllani 2006: 128)

[...] It's a tough life because in many cases the police fire warning shots to scare you and somehow manage to get you in the back of your head with uncanny mathematical precision. Afterwards the policeman gets off and nobody loses their sleep over it.

(Kapllani 2009: 107, translated by Stanton-Ife)

The TT narrator attacks the murderous tactics of policemen in a more accessible style, evident in contractions (the non-metaphoric 'it's a tough life') and phrasal verbs ('get you,' 'gets off'). It also features an additional ironic cue, the adjective 'uncanny.' The translator's penchant for ironic additions ostensibly distorts the voice of the narrator, but it renders the link between statements about discrimination and comic 'self-presentation' of migrants as cultural caricatures more poignant. Amplified across most chapters, irony becomes a coherence-boosting technique; it shows how ineffectualness morphs into discrimination and vice versa. It is this irony and direct, 'spoken' style that translation reviewers also noticed. Tonkin (2009) and Zinovieff (2009), among others, have praised the topics, the colloquial English and ironic style, which may have contributed to the shortlisting of the book for the TLS translation prizes in 2013 (Tahourdin 2013).

The last technique concerns the rewriting of the epilogue and its subsequent translation into English. Although this was a decision taken by the author and the publisher and not the translator, it can shed light on Balkan marginality. The ST epilogue is framed as an open letter to readers. It starts off with captatio benevolentiae, pointing to the narrator's wish not to bother readers with the details of a personal decision to follow the paths of ksenitia (Kapllani 2006: 175). Then, the diarist-narrator employs paralepsis; he precisely describes his experiences in the past year: the anxiety of not being able to plan ahead, the long queues in various Greek institutions and numerous instances of bribing 'middlemen' to beat bureaucracy. When he realises that his Albanian passport is about to expire, he visits Albania, a country now ruled by venal politicians and corrupt officials. He finds out that his former teenage sweetheart, who was sold as a sex-slave, was forced to brutally kill her pimp. An old friend, a former political prisoner of the Hoxha regime, admonishes him to seek a better life abroad. Finally, he realises he cannot renew his passport without bribing a middleman generously, so he leaves Albania empty-handed. After being subjected to a humiliating search by Greek border policemen, he reaches Athens and resumes the hunt for a new set of documents (immigration legislation changed while he was away). The epilogue ends with the narrator wondering why one cannot take root in the country where they live and where their (already assimilated) children will grow up. These are the realities Greeks know yet refuse to see. On the one hand, the desirable public image of Greek society is one where civic values are highly important. On the other, corruption is rife, the state cannot be trusted and laws 
change constantly, depending on where the political wind blows. All of the above are causes for embarrassment. The epilogue seems to imply that, to a certain extent, Greeks share such realities with another Balkan nation, one that is yet to join the EU. Also, it suggests that ethnic Greeks are perhaps even less aware of the fact that migrants experience the full force of such tensions. Migrants are stuck between a socially and politically corrupt country of origin and an unsympathetic foreign land exhibiting a similar moral bankruptcy.

The TT is much shorter and offers a sense of closure. While both the original introduction and conclusion are personal/italicised sections, the TT epilogue is nonitalicised; paired with the italicised introduction, it mimics the sequential dynamism of italicised/non-italicised sections all other chapters. There is a sense that the TT epilogue comes full circle content-wise too. It addresses the so-called border syndrome that the narrator mentioned in the introduction yet avoided to define (creating narrative suspense). The narrator uses a somatic analogy (virus) to explain border syndrome, the cultural deficiency that singles migrants out as 'other' and which motivates them to keep the struggle for survival in their new home. Interestingly, the

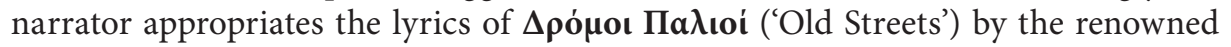
Greek composer Mikis Theodorakis to emphasize the emotional impact of border syndrome; this is a Greek song not specifically written for Albanian migrants but here it is repurposed to capture the pangs of isolation and the fear of failure.

Internationalising the novel even further, the epilogue shows the diarist-narrator visit the Berlin Wall. The narrator's gaze is dramatically different from that of affluent tourists around him. For him, the wall is a reminder of state control. The novel ends with a positive clarity of vision: migration is a cycle; present-day immigrants will one day be able to hold 'cool' passports and travel freely, just as many before them did (including Greeks, Germans, Italians and Irish); irrespective of our role and bearing in societies with borders, we are all "armed with temporary residence for this earth, each and every one of us incurably transient” (SBH: 157). When I asked the author why the epilogue was rewritten, he simply reported that he was not happy with the original version and that the TT version is the one he would have preferred to use for his novel. It seems that translation offered a unique creative opportunity. The TT is balanced, shorter and more coherent. Moreover, translation created a space for managing cultural intimacies. Had Kapllani/the translator dwelt on inconvenient truths about the Balkans, which can be effective for Greek audiences, they would have risked activating stereotypes about the region among an international audience. To build on Kapllani's Berlin reference, the TT epilogue elaborates an argument of die Mauer im Kopf ('the wall within the mind') that an international audience can identify with. Migrant stigma is a certainty that can be ironically reversed, because migration is a historical cycle, not a spectacle one's vantage point of security or affluence allows. Such ironic identification is taken a step further in Tsitos' film.

\section{Losers in the Academy}

Tsitos was born in Athens in $1966^{2}$. He studied Business Management at the Economics University of Athens. At the same time he freelanced as a director's assistant, radio show producer and photographer. In 1991 he moved to Berlin to take a film directing course at the Deutschen Film- und Fernsehakademie. Since 1992 he 


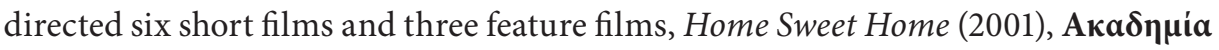

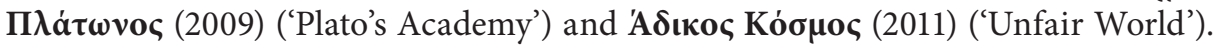
Like many of his films, Plato's Academy, is a German-Greek co-production and Tsitos is the co-author of the script (in this case, with Alexis Kardaras). The film was positively reviewed at international festivals, receiving three prizes at the Locarno International Film Festival in 2009: the Universal Award, the Best Actor Award for Antonis Kafetzopoulos, and the third Award for Newcomers.

Tsitos' film is about Stavros (Kafetzopoulos), a xenophobic owner of a tobacco/ small goods shop at an odd five-street juncture in a run-down neighbourhood in Athens. Stavros, whose wife has left him, looks after his senile mother Charikleia (Titika Saringouli), suffers from insomnia and spends most of his time outside his bleak-looking shop, with his fellow shop owners from across the street(s): Argyris, Nikos and Thymios, all in their late forties. The four scruffy-looking friends indulge in their daily routine of inactivity: they sit on chairs outside Stavros' shop and comment on whatever happens around them. Their main focus is the bustling activity of 'foreigners,' including Albanian workers who have been hired to build a municipal 'international solidarity' monument. The DVD extras include comments by Tsitos that summarize the main cultural intimacy issue in the film: these are men who have lost their identity; they can hide the emptiness of their lives only by directing dismissive comments at those who are culturally different.

The film contains one major ironic reversal: one day, Stavros' mother calls out to an Albanian worker named Marenglen (Anastas Kozdine) by the name 'Remzi'; she talks with him in fluent Albanian and reveals to Stavros that Remzi is his brother, thus shattering the only certainty in Stavros' life, his Greekness. Stavros grudgingly gets to know Marenglen so as not to aggravate the health of his mother who has suffered a stroke. Simultaneously, he stubbornly defends his Greek identity in the eyes of his increasingly suspicious friends. The latter still show 'mates camaraderie' but their uncomfortable questions anger Stavros. Stavros comes to terms with his identity at the end of the film when Charikleia dies. At the funeral, Marenglen confesses that he has told himself and Stavros a white lie, that is, Charikleia is not his mother; her fluent Albanian, her appearance, her kindness and her migration story were simply so convincingly similar to Marenglen's own memories of his own mother that he wished to believe he had found his long lost "safe haven" (Tsitos 2009, DVD extras).

Plato's Academy points to existential loneliness and the lack of trust within a nation (Calotychos 2013: 195). It is a film that marks a process of maturation in migration topics in Greek cinema, a phase of "postsentimental identification beyond alienation" (Calotychos 2013: 161). In this sense, parallels can be drawn with Kapllani's precedent setting. Just like A Short Border Diary, Tsitos' film came out when Albanian immigrants had established themselves in Greek society. Films with Albanian protagonists were hardly successful commercially and/or caused controversy until this point; yet Plato's Academy was the first film to successfully tackle the issue of modern Greek identity and xenophobia head-on by combining a non-didactic tone, sensitivity, realism and sarcasm with a clever identity reversal (Katsounake 2009; Vasileiou 2009). Further similarities with Kapplani's novel can be detected in the bitter-sweet comedic distance between the (script) author and characters. Characters in Plato's Academy are caring, funny as well as xenophobic 'losers' beset by inertia. Uncanny similarities emerge on a narrative level too, which suggest that 
Tsitos actively used Kapllani's ideas. ${ }^{3}$ Finally, both the film and the novel use a general gesture of projecting the specific/personal onto the communal/general; Stavros' predicament, his neighbourhood, his attitudes allude to broader issues of belonging in any multicultural society. In what follows I will discuss three identity-related characteristics: liminality in the visual code, xenophobic statements and the use of Albanian.

The film is deeply ironic. It conveys the incongruities between the ideal universe imagined by the Academy's inhabitants and reality. Relevant ironies are conveyed through all the channels available to the director and the anonymous subtitler has attempted (more or less successfully) to relay them. The film's pace and general iconographic symbols convey a feeling of inertia. Buildings, vehicles, shops, graffiti, clothing and people themselves offer layers upon layers of developments in the last 40 years: partial industrialization, internal migration, building boom (in the grim block-flat style of the 1970s and 1980s), overpopulation of urban centres, trade deficit and obsession with foreign products/consumerism, the arrival of immigrants from Albania (and elsewhere), economic stagnation. Stavros' neighborhood is a (visually) dull space that retains a tension between timelessness, which Stavros and his friends endorse, and change, to which they turn a blind eye. The title of the film sustains this tension. It refers to the real, run-down western district of Athens called Plato's Academy, in whose vicinity the archaeological site of the historical Academy can be found. Greek viewers can immediately discern the incongruity between the glory of Ancient Greece and the decadence of this corner of Athens. The rather literal translation of the title undermines this intention. ${ }^{4}$

Perhaps the most culture-specific symbol in the film is the intercultural solidarity monument, whose construction the four friends strongly oppose. Stavros speechifies angrily when municipality representatives visit the 'encroached' area (00:28:2500:28:55). He warns them about the next elections and delivers a threat: “ $\Theta \boldsymbol{\alpha}$ ' $\rho \chi \boldsymbol{\varepsilon} \boldsymbol{\sigma} \tau \boldsymbol{\varepsilon}$

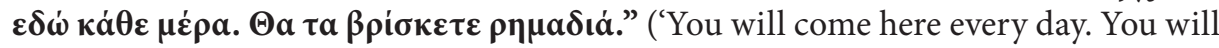
find rubble[+slang]'). Stavros and his friends act upon this threat many times, usually under the cover of darkness, in order to reclaim the juncture as a football playing/ watching area. They only give up towards the end of the film, and the very closing scene shows all four of them sitting outside Stavros' shop staring at the ready-to-beinaugurated monument. I consider this 'theme' a visual translation of the Bridge of Arta ballad. According to lore, master builders would work on the bridge only to find it in ruins the next morning, until a (personal/human) sacrifice was made. There are various versions of this myth in the Balkans, which has been elaborated or problematized in literature to signal liminality, connection and/or separation of local communities "brought about by the external, written, and legal interventions of the Great Powers in the age of nationalism" and beyond (Calotychos 2013: 101). Here the monument visually indicates that Stavros sacrificed his beliefs/earlier identity in order to move on; the penultimate scene where an insomniac Stavros manages to sleep undisturbed after his mother's funeral supports this interpretation. Stavros' mother herself can also be seen as an agent of sacrifice as she has kept a latent Albanian side throughout her adult life in Greece only to reawaken when she meets Marenglen. Her invisible cultural identity probably serves as an allegory of Albanian migration within the Balkans/Greek lands as well as varying degrees of integration. Albanians often changed their religion and language in the last two centuries in order 
to fit in or to avoid conflict and persecution. The Greek state has (historically, and) actively denied such connections with ethnic Albanians since the beginning of the $20^{\text {th }}$ century, amidst population exchanges or political/military turmoil, and most notably after World War II (see Elsie, Destani, et al. 2012).

In light of the above, I disagree with reviewers who argue that there is no transformation in the end. Weissberg (2009) maintains that visuals and characterisation are flat, that the film recycles stereotypes and that viewers may "go home feeling comfortable." An anonymous reviewer in the Imdb entry for the film ${ }^{5}$ is more positive about the quality of the film, but s/he also claims that the film offers insights into Greek society and that in the end everything goes "back to normal." Arguably, the film's tempo matches the ennui in Plato's Academy [sic], the ending is sufficiently open-ended and there is definitely more than meets the eye. Maybe there is no explicit indication that Argyris, Nikos and Thymios have changed like Stavros, but they too are witnesses to a monument that was built by Albanians in a neighbourhood with increased Chinese presence. Neither the director nor the subtitler has control over the reception of such culturally embedded signs. Yet the literal rendition of Stavros' threat above as "Every morning,/you will find it in ruins!" is a missed opportunity to hint at the significance of this utterance (for example, by using an idiom or equivalent cultural allusion that may draw attention to the liminality of bridges). On the other hand, there are moments when the subtitler has (un)intentionally detected ideologically relevant text. At 00:43:13 Chinese workers are trying to put up a sign for their new shop at night. The sign features Chinese characters, the owner's name and a 'contact us' section in English, plus some Greek text. Although there would be no need for translation, the subtitler has rendered it as "Italian fashion Wang Lian." By rendering 'Italian fashion' (which was in Greek), the subtitler hints at the fact that bridge building is now governed not by ethnic identity but by the constraints/opportunities of globalisation. Such interventions are the exception rather than the rule in the film.

The second main focus of the film is xenophobia. Exaggerations and clichés are used throughout, clearly portraying those who use them as satirical targets and revealing the failings of Greek 'philoxenia.' Subtitles are moderately effective here. For example, Nikos, keeps his dog on a strict diet so that he can hone his ability to sniff out and bark at Albanians (00:11:12-00:13:20) - arguably, a manifestation of "the age-old European" practice of "nasal racism," or detecting the unpleasant odour of

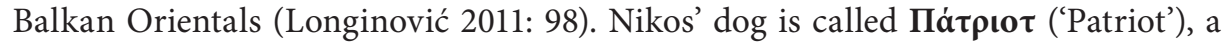
phonological translation from the English. 'Patriot' is used as a loan word in Greek only when referring to the American surface-to-air missile system introduced during the Gulf War in 1991. The dog's name comically maps Albanian detection onto Republican politics and their war machine. English subtitles by necessity employ 'Patriot' and sustain a satirical canine/human ambiguity, but Nikos' conflation of dog training and politics could have been compensated for. When Patriot barks at

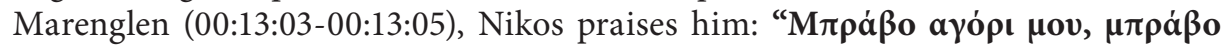

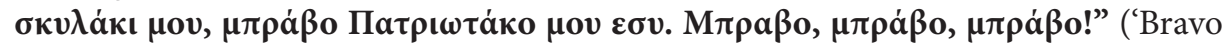
my boy, bravo, my doggie, bravo, my Patriot[+diminutive] you. Bravo, bravo, bravo!'). The English subtitles read: “That's my boy!/That's my Patriot, good boy!” The Patriot/patriot ambiguity could have been foregrounded even more, for example, by conveying more of Nikos' effusiveness or by introducing a politically tinted term. 
Space/time constraints in this entire sequence certainly allowed the addition of more text.

Similarly, more creative solutions are needed when rendering the rhyming chant used by Argyris (00:13:55) and again by everyone when watching a match (01:01:45-

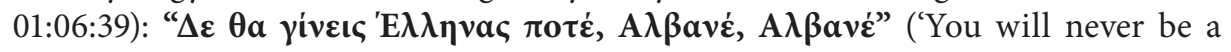
Greek, Albanian, Albanian'). This is a racist ditty sung initially by football fans when Greece lost to Albania in the UEFA European Championship (04.09.2004). Far-right groups also sung it when they went on a rampage and beat up 'foreigners' after the match. Tsitos has Greece win in the fictitious match of the film. The camera comically cross-cuts to the reactions of an Albanian group Marenglen has joined to watch the match and those of Stavros and his friends. The chant becomes audible through the TV sets as the two groups watch. After the victory goal is scored, the Greek entourage celebrates wildly, singing the chant. Suddenly, it dawns on them that it does not make sense for Stavros to chant (Stavros gets offended and makes a funny exit by unplugging the TV and unceremoniously closing the shop). The Greek language allows the use of nationality nouns in the singular to refer to 'people.' In the subtitles, the chant was repeatedly rendered as a reference to 'some' Albanian, that is, Stavros, which is somewhat forced, because it does not sound natural as a generic reference to Albanians, and therefore as an authentic chant football crowds could have used: “Albanian,/you'll never be a Greek!" A less 'cautious' approach could have compensated for the allusion here; evaluative terms spelling out the Greek-Albanian divide, or an alternative rhyming chant, possibly in slightly varied couplets, could have been much more effective.

Other clichés are affected by a tendency towards a particularisation technique in the subtitles. In example 4 below, for instance, Nikos objects to Stavros' hiring an Albanian to help him out with his mother. Stavros in fact pretends to do so in order to conceal his relation with Marenglen. The ST sounds very absolute: Albanians should be barred from private spaces, as a matter of principle. The subtitles, on the other hand, gesture towards a stereotype of criminality.

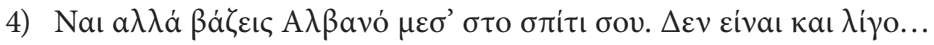

[[Nikos] Yes but you put an Albanian in your house. This is not a small thing...]

(Tsitos 2009: 00:27:06-00:27:08)

a. Yean, but you have an Albanian/in your own home.

b. That's risky.

(Tsitos 2009, subtitles)

At other times, the particularisation technique backfires entirely. In his perennial search for an Albanian to help him mend the house, Argyris wants to ensure Marenglen's number is saved on his contact list. Example 5 is a close-up of his mobile:

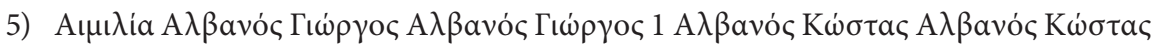

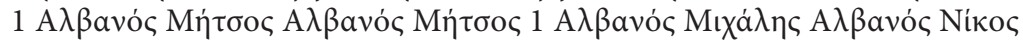
[Aemilia Albanian Yorgos Albanian Yorgos 1 Albanian Kostas Albanian Kostas 1 Albanian Mitsos[+slang] Albanian Mitsos 1 Albanian Michalis Albanian Nikos]

(Tsitos 2009: 00:54:41-00:54:43)

Albanian John, Albanian Harry,/Albanian Philip, Albanian Nikos.

(Tsitos 2009, subtitles) 
The first time Mareglen met the four friends and was asked for his mobile number by Argyris (00:13:25) he introduced himself as Nikos (Stavros angrily rebuked him, asking for his real name). Name changing among Albanians is a very common strategy of circumventing stereotypes and social exclusion (Schwandner-Sievers 2003: 112). Argyris reinstitutes stereotypes and social exclusion: his contact list starts with the Greek 'Aemilia' and as he scrolls down he reveals a series of 'other' Greek names, including a familiar/slang version for 'Dimitris' (Mitsos). Unlike 'Aemilia,' these 'other' names have duplicates, marked with number 1 , and they all start with a disambiguating 'Albanian.' The subtitler has provided a strange mixture of localised names, plus Marenglen's 'Greek' name, Nikos. The result is culturally uneven or potentially confusing. It also seems that the subtitler did not resist the temptation to manage redundancy, a very common norm in document translation that often becomes even more pressing under the space constraints of subtitling. The point that many Albanians were prepared to give Argyris Greek names or that Argyris never bothered to ask for 'exotic' first/last names is muddled.

Xenophobic statements are also diluted when the translation is vaguer, which shows that a good balance between the general and the specific must be struck for the sake of characterisation. The excerpts in examples 6 and 7 come from the scene where the four friends observe Albanians constructing the solidarity monument and Chinese workers stocking their new store. In example 6, Nikos argues that the Chinese are better than the Albanians. In example 7, Stavros says he has sent 'his' Albanian (i.e., Marenglen) away.

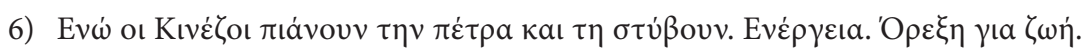
[[Nikos] While the Chinese grasp a stone and squeeze it[:idiom = 'are strong']. Energy. Appetite for life.]

(Tsitos 2009: 00:53:52-00:53:59)

a. The Chinese/are bursting with life.

b. They have a zest for life.

(Tsitos 2009, subtitles)

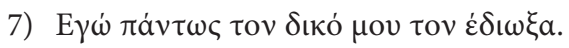

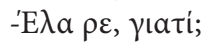

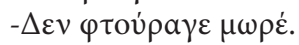

[[Stavros] But I sent mine away.

[Argyris] How come, re[:surprise particle]

[Stavros] He did not do[+slang: 'was enough/appropriate'] more[:friendly vocative].]

(Tsitos 2009: 00:13:03-00:13:05)

a. I sent mine away.

b. -Why?/ - He wasn't any good.

(Tsitos 2009, subtitles)

Both Stavros and Nikos deploy clichés recalling dominance relations between native 'bosses' and foreign 'workers.' Idioms referring to physical strength 'clinch' their 'theory': 'to squeeze a stone' in example 6 means to be physically strong; similarly, Stavros' slang idiom in example 7 refers to 'quality of performance,' 'suitability' and 'stamina' (it is generally used for objects too, when they are sufficient in quantity). The subtitler backgrounds physical description. The TT in example 6 uses idioms referring to levels of energy while the idiom in example 7 focuses on quality. Bustling 
activity around these out-of-shape, lethargic arbiters of performance still primes them as targets of satire. However, racial overtones are toned down when they should be an important aspect of characterisation.

The last cultural intimacy issue concerns the use of Albanian as a channel of contact between characters and viewers. Audiences experience Albanian in three ways: a) mediated by Marenglen who interprets what 'mom' says; b) completely unaided; c) with the help of subtitles. Thus, in the beginning of the film, Marenglen joins Charikleia for dinner and translates, so that Stavros can follow. At 00:20:22-00:22:08 and 00:26:16-00:26:18 the story of Charikleia's migration unravels: after her husband's death she decided to flee to Greece, but had to leave Marenglen behind because he fell sick on the eve of the trip. Greek viewers can probably recognise cognates in the above interactions (babai 'father' and hajde 'go on'). English-speaking audiences at this point are 'trained' to expect Albanian in Charikleia's interactions with Marenglen.

After this point, no further assistance is provided for Greek audiences, whereas subtitles continue to be available for English-speaking audiences. During a supermarket visit (00:30:11-00:30:43) Marenglen explains to Charikleia how he got his name and what it means. After a few exchanges, they finish their conversation with the following (available in English subtitles only): “-Let's stick to Remzi, please. - I didn't know/my name was Remzi." The names are audible, but subtitles in Greek would be necessary for viewers to see that Marenglen identifies holes in the family reunion narrative. There are more places when Greek viewers are excluded. For example, at 00:41:31-00:41:38 Charikleia bonds with Marenglen by recounting stories from Stavros' adolescence, commenting that the two 'brothers' have a similar taste in music. Non-translation creates a different identification dynamic. Englishspeaking audiences have direct access to significant moments for the plot, while Greek viewers confront linguistic otherness and are forced to work harder, seeking clues in cognates, gestures and the overall context.

Towards the end of the film, both Greek and English-speaking audiences need to watch and/or listen actively without any linguistic mediation. At 00:45:25-00:47:26 Marenglen and Stavros finally give in to their mother's wish to have a night out at a 'folksong Albanian nightclub.' The singer at the venue asks individuals to sing the first couplets of a song before she takes over. Stavros is asked to sing too, first by the singer and then by Charikleia, only to be extricated from this awkward situation after Marenglen's intervention. The subtitler treated the entire sequence as extradiegetic sound, using a caption within square brackets, "[Albanian]," to signal the code switch. Similarly, it is all Albanian for Greek viewers. However, the latter can experience familiar linguistic, musical and iconographic signs: cognates in Charikleia's admonition (këndo hajvan, këndo hajvan, meaning 'sing, you stupid/animal' - most of these cognates come via Turkish; see Balaban and Çağlayan 2014); cognates in the song (the exclamation "aman yaman"); the genre of the folksong as such; the open circular dance. Because of these recognisable markers, Greek viewers can readily appreciate the (comic) tension between the oriental, Balkan, and by extension Greek, traditionalism of this scene and Stavros' passionate appreciation of western rock music. Throughout the film, Stavros describes rock music as a way of life or an excuse for rebellion (without specifying what he is rebelling against). The intimacies of cultural consumption here help to establish coherence (denial of past) and to show the common cultural stock between Greeks and Albanians. 


\section{Degrees of separation}

If the discourse of balkanism is to be investigated in all its complexity, the concept of cultural intimacy should be used as a concrete semiotic tool of cultural critique. As was shown in this paper, cultural intimacy can be examined bottom-up, through the prism of either written or multimodal texts. It can also be used as an evaluation tool for translations produced at key historical moments. In the case of works that specifically focus on the stigma of migration, translation offers distinct opportunities for understanding identity. First, the channels of communication open, allowing visibility for cultural groups that would otherwise remain invisible. Secondly, translation may mediate the apparent (dis)comfort zones of majority and migrant socialities, by showing or critically citing inconvenient truths across language barriers. The two works examined here focus on Albanian-Greek encounters, foregrounding a common cultural stock (contrary to official models of identity that dictate otherwise) as well as satirising exclusionary practices or views. Both works exhibit similarities and discrepancies on account of being 'firsts' in terms of reception, featuring similar communal-personal perspectives (and even content) and, obviously, employing different media.

Kapllani's Short Border Diary covers the journey of migration, from the moment of leaving Albania behind to negotiating acculturation. A narrator presents migrants as underdogs who consistently fail to be integrated, because the host culture is not as accepting as everyone thinks. Here the translator was very creative. Not only did she shadow the rhetorical moves of the ST, but she also (over)interpreted the voice of the original vis-à-vis orality and irony. Interestingly, the conclusion of the novel was entirely rewritten, most probably in an attempt to avoid getting stymied in specific cultural intimacies that are effective in the Balkans but prone to generate stereotypes beyond the Balkans. The positive reception of the novel in the UK points to the effectiveness of this approach.

In Plato's Academy, looking through the eyes of a stranger entails an identity reversal, or showing the story of a Greek who is not who he thinks he is. The filmic medium here allows certainties of ethnic origin to be deconstructed through a series of visual and linguistic incongruities. In translation, opportunities for creative renditions that could present characters in an absurd light were missed but the subtitler attempted to create a smooth viewing experience, producing idiomatic translations and filling in certain gaps (for example, interactions in Albanian). The main challenge was to avoid recycling stereotypes, as reviewers have thought. To complicate matters even more, the film was released immediately after the economic crisis; thus the 'laziness' of the characters could be seen as a cause of the crisis itself. For such a temporally- and culturally-bound film, perhaps further intervention is required by the subtitler or the director. The former could signal the film's satirical import through appropriate cues; the latter could offer a rewritten, alternative ending for the DVD release, or a detailed explanation in the DVD extras that can frame the film as a satirical portrayal of Greek reality.

Needless to say, the study of cultural intimacy can shed light on the synchronic/ diachronic development of Balkan identities if extended to other areas. According to Herzfeld, changes "in the intimate reaches of everyday life" or the "global distribution of power" are indicators of the shifting content of "the intimate zone that may give 
rise to embarrassment" (Herzfeld 2005: 31, 65). As a recreation of messages across media, time and genres, translation is ideally positioned to capture tensions between public display and insider-knowledge - perhaps even more so in translation reception studies where self-presentation of viewers/readers may be shown to feed into or clash with public narratives of identity. Product-oriented studies may focus on translations where heritage, ideology or morality are key, such as historiography, tourism, journalism or religious texts. They too can answer significant questions on identity, especially with respect to how 'continuity' or 'tradition' is (mis)construed. Finally, certain 'themes' may readily lend themselves to the examination of intimate zones. The theme discussed here was migration. Other cycles of migration can be examined, possibly in the light of the current economic crisis, itself a topic that affects negative self-designation at home and external identification as a liability internationally (see section 1). As the age of migration converges with an age of uncertainty, cultural intimacies may multiply and interact, with the help of translation.

\section{NOTES}

1. Anne-Marie Stanton-Ife read Modern Languages at Cambridge and did an MA in Comparative Literature at UCL. She taught Translation Studies at the British Council in Athens and started off translating short texts, mainly for cultural organisations and publishers in Greece. Her first book length translation was the biography: Quisling. A Study in Treachery (2007) by Hans Fredrik Dahl (Cambridge University Press).

2. Internet Movie Database, www.imdb.com.

3. Both the film and the novel have a character named Marenglen and explain the semi-comedic fact that it is a portmanteau of Marx, Engels and Lenin. Both use specific references to China: the odd cultural ties between Albania and China under Hoxha's rule, and even a whole chapter/scene revolving around tai-chi practice. Kapllani and Tsitos use the same racist football chant as a prompt for social commentary (see below).

4. The German title, Kleine Wunder in Athen ('Small Wonders in Athens'), for example, is ironic without any reference to Plato's Academy.

5. Internet Movie Database. Plato's Academy. http://www.imdb.com/title/tt1334313/reviews?ref_=tt_ urv

\section{REFERENCES}

Asimakoulas, Dimitris (2013): Migrant Bitter Wit: Translating a Coping Mechanism in

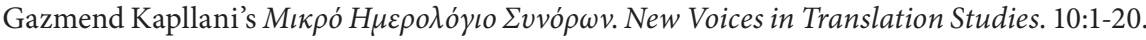

Balaban, Adem and ÇAgaĞlayan, Bünyamin (2014): Common Cultural Turkish Words in Albanian and Greek. Journal of Educational and Social Research. 4(2):267-270.

Calotychos, Vangelis (2013): The Balkan Prospect. Identity, Culture, and Politics in Greece after 1989. New York: Palgrave McMillan.

Carbonell Cortés, Ovidi (2003): Semiotic Alteration in Translation. Othering, Stereotyping and Hybridization in Contemporary Translations from Arabic into Spanish and Catalan. Linguistica Anverpiensia. 2:145-159.

Cheliotis, Leonidas (2013): Immigration Detention and State Denial in Greece. Open Democracy. Visited 28 July 2016, <http://www.opendemocracy.net/can-europe-make-it/leonidaskcheliotis/immigration-detention-and-state-denial-in-greece $>$.

Christopoulos, Dimitris (2009): Defining the Changing Boundaries of Greek Nationality. In: Dimitris TzIovas, ed. Greek Diaspora and Migration since 1700. Society, Politics and Culture. Farnham, UK: Ashgate, 111-123.

Elsie, Robert, Destani, Bejtullah and Jasini, Rudina, eds. (2012): The Cham Albanians of Greece: A Documentary History. London: I. B. Tauris. 
Farinou-Malamatari, Georgia (2003): The Representation of the Balkans in Modern Greek Fiction of the 1990s. In: Dimitris TzIovas, ed. Greece and the Balkans: Identities, Perceptions and Cultural Encounters since the Enlightenment. Aldershot, UK: Ashgate, 249-261.

GotsI, Georgia (2012): Beyond 'Home Identity': Immigrant Voices in Contemporary Greek Fiction. Journal of Modern Greek Studies. 30(2):155-189.

Herzfeld, Michael (2002): The Absence Presence: Discourses of Crypto-Colonialism. The South Atlantic Quarterly. 101(4):899-926.

Herzfeld, Michael (2005): Cultural Intimacy. Social Poetics in the Nation-State. $2^{\text {nd }}$ ed. London/ New York: Routledge.

Jones, Francis R. (2004): Ethics, Aesthetics and Decision: Literary Translating in the Wars of the Yugoslav Succession. Meta. 49(4):711-728.

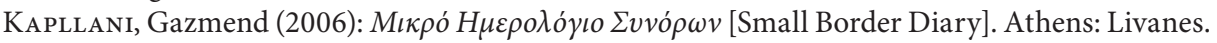

Kapllani, Gazmend (2009): A Short Border Handbook (translated from the Greek by AnneMarie Stanton-Ife). London: Portobello Books.

Kasimis, Charalambos (2012): Greece: Illegal Immigration in the Midst of Crisis. Migration Policy Institute. Visited 28 July 2016, <http://www.migrationpolicy.org/article/greece-illegal-immigration-midst-crisis $>$.

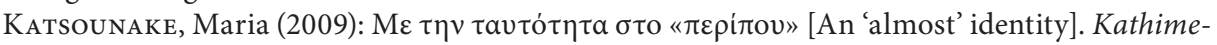
rini. 15 October 2009. Visited 28 July 2016, <http://www.kathimerini.gr/373063/article/ politismos/arxeio-politismoy/me-thn-taytothta-sto-peripoy>.

KING, Russel (1998): Post-Oil Crisis, Post-Communism: New Geographies of European Migration. In: David Pinder, ed. The New Europe: Economy, Society and Environment. Chichester, UK: Wiley, 281-304.

KLonovsky, Michael (2010): 2000 Jahre Niedergang. Focus Magazin. 22 February 2010. Visited 28 July 2016, <http://www.focus.de/finanzen/news/staatsverschuldung/wirtschaft2000-jahre-niedergang_aid_482500.html>.

KuhiwCZAK, Piotr (1999): Translation and Language Games in the Balkans. In: Gunilla AnderMAN and Margaret Rogers, eds. Word, Text, Translation. Clevedon: Multilingual Matters, 217-224.

Longinović, Tomislav (2011): Vampire Nation. Violence as Cultural Imaginary. Durham/ London: Duke University Press.

Nitsiakos, Vassilis and Mantzos, Constantinos (2003): Negotiating Culture: Political Uses of Polyphonic Folk Songs in Greece and Albania. In: Dimitris Tzıovas, ed. Greece and the Balkans: Identities, Perceptions and Cultural Encounters since the Enlightenment. Aldershot, UK: Ashgate, 192-207.

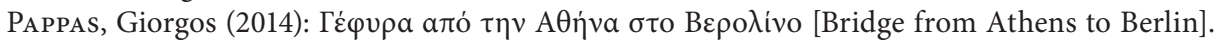
Ta Nea. 14 June 2014. Visited 28 July 2016, <http://www.tanea.gr/printed/tanea/article?pre mium $=1 \& d=20140614 \&$ aid $=25493963>$.

Schwandner-Sievers, Stephanie (2003): Albanians, Albanianism and the Strategic Subversion of Stereotypes. In: Andrew Hammond, ed. The Balkans and the West. Constructing the European Other, 1945-2003. Aldershot, UK: Ashgate, 110-126.

Stahuljak, Zrinka (2010): Translation, Conflict, and Postcolonial Critique. In: Moira InghilLERI and Sue-Ann Harding, eds. Translating Violent Conflict. Special issue. The Translator. 16(2): 255-274.

Svensson, Anette (2010): A Translation of Worlds: Aspects of Cultural Translation and Australian Migration Literature. Umeå, Sweden: Umeå University, Department of Language Studies.

TAhourdin, Adrian (2013): Translation Prizes. The Times Literary Supplement. 31 January 2013. Visited 28 July 2016, <http://www.the-tls.co.uk/articles/public/translation-prizes/>.

Todorova, Maria Nikolaeva (2009): Imagining the Balkans. Updated ed. Oxford: Oxford University Press.

Tonkin, Boyd (2010): A Short Border Handbook by Gazmend Kapllani. The Independent. 21 May 2010. Visited 28 July 2016, <http://www.independent.co.uk/arts-entertainment/books/ reviews/a-short-border-handbook-by-gazmend-kapllani-1978240.html>. 
Tsianos, Vassilis and Karakayali, Serhat (2010): Transnational Migration and the Emergence of the European Border Regime: An Ethnographic Analysis. European Journal of Social Theory. 13(3): 373-387.

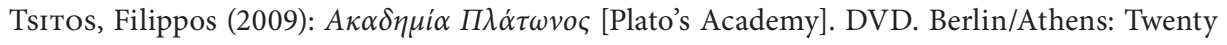
Twenty Vision and Pan Entertaintment.

Tziovas, Dimitris (2003): Introduction. In: Dimitris Tzıovas, ed. Greece and the Balkans: Identities, Perceptions and Cultural Encounters since the Enlightenment. Aldershot, UK: Ashgate, 1-15.

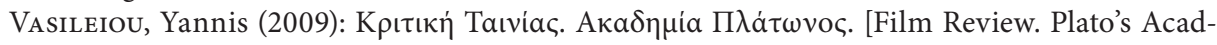
emy]. Cinema News. Visited 28 July 2016, <http://www.cinemanews.gr/v5/movies.php?n= 6757>.

Weissberg, Jay (2009): Review: 'Plato's Academy.' Variety. 17 August 2009. Visited 28 July 2016, $<$ http://variety.com/2009/film/reviews/plato-s-academy-1200475622>.

Wright, Chantal (2010): Exophony and Literary Translation. Target. 22(1): 22-39.

ZinoviefF, Sofka (2009): Broken Biscuits. The Times Literary Supplement. 20 November 2009. Visited 28 July 2016, <http://www.the-tls.co.uk/articles/public/broken-biscuits/>. 